\title{
TONE IN SEZO
}

\author{
Girma Mengistu Desta
}

\section{ABSTRACT}

Sezo has two levels of tone - high and low. The two tones occur on monomoraic and bimoraic syllables (i.e. on short and long vowels). Rising (LH) and falling (HL) contour tones have been recorded occurring only on bimoraic syllables. They are analyzed as composites of the high and low tones squeezed together on one bimoraic syllable as a result of diachronic and synchronic processes. Tone plays a very significant role in the lexicon of the language. It distinguishes lexical items. It also derives nominal stems from verbal roots. Unlike its importance in the lexicon, tone has a limited role in the grammar of the language. The only grammatical function of tone is to make a distinction between declarative and interrogative sentences. The key tonal processes in the language are downdrift, downstep, contour formation and total spreading of a high tone. Contour tones are formed through the partial spreading of a high tone over a low tone bearing unit and the re-linking of a floating high tone to an adjacent low tone bearing unit.

\section{[1] INTRODUCTION}

Sezo is an endangered Omotic language classified as a member of the NonGonga group of Mao languages (Fleming 1984: 35). It is spoken in the western borderland of Ethiopia in the Begi and Guddattu Qondala districts of the West Wellegga administrative Zone within Oromia Regional State. The speakers of Sezo are estimated as numbering between 7,000 and 10,000 (Girma 2015:2).

Sezo is a tone language. It is not a pitch-accent language because the location of a high pitch in a given word class is not predictable. According to Fox (2000: 179), a pitch-accent language 'involves the use of pitch in an accentual function, i.e. to give prominence to one particular element [...]'. Pitch-accent is assigned to either a prominent or a stressed syllable (Yip 2002:276). In Sezo, however, lexical items of comparable syllable structure can be divided into different groups only by their pitch variation. A word may not involve a high pitch at all. 
This paper ${ }^{1}$ intends to give a brief but comprehensive description of the tone system of Sezo. The discussion is presented in six sections, the first one being an introductory section. Section 2 describes the methods of collecting and presenting data. Section 3 deals with the inventory of tones. Section 4 provides acoustic evidence for the contrastive tones. This is followed by Sections 5 and 6 which respectively deal with the description of the lexical and grammatical functions of tone and various tonal processes. Section 7 concludes the paper.

\section{[2] METHODOLOGICAL CONSIDERATIONS}

The data used in this study were collected between 2011 and 2014 in different villages of the Begi and Guddattu Qondala districts of the West Wellegga Zone and in Asosa, the capital of the Benishangul Gumuz Regional State. In order to identify the contrastive tonal melodies on lexical morphemes and to establish the number of level and contour tones, lexical items were gathered from native speakers of the language through series of group sessions. During the group sessions, specific semantic domains of words were used to build up the vocabulary. Each word was transcribed on a separate slip of paper. The transcribed words were then subdivided into different subgroups on the basis of their similarity in morphological form and syllable structure. Words in each subdivision were repeatedly pronounced and whistled by native speakers so that the surface tonal melodies in each word class could be identified. Finally, the underlying tones of the language have been established on the basis of the identified surface tonal melodies.

In order to discover how the different tones behave following or preceding other tones in particular syntactic constructions, frames, carefully constructed phrases and natural texts were used. In this study, the pitch tracks and acoustic measurements of contrastive tones and various tonal processes are demonstrated by a software program known as 'Speech Analyzer', retrieved from http://www.sil.org/computing/sa/index.htm. All the acoustic measurements have been carried out by the author.

\section{[3] THE INVENTORY OF TONES}

Sezo is a two-tone language. The two tones-high (H) and low (L), are able to occur on both monomoraic and bimoraic syllables. The inventory of the tones is based on contrastive pitches attested on disyllabic nouns, adjectives and

[1] This article is a modified version of a chapter on tone in my Ph.D. thesis which was submitted to the Department of Linguistics, Addis Ababa University in 2015. Only some data have been added in $\S 5.1$ of this paper. 
verbs. Disyllabic words were chosen for the inventory of tones, because they constitute more than $90 \%$ of the Sezo lexicon. In order to make the inventory of nominal and adjectival tonal melodies, the citation form of nouns and adjectives have been used. In the citation form, nouns and adjectives consist of lexical roots and terminal vowels (hereafter "TV"). The function of the TV of a noun or an adjective cited in isolation is to host the root-final floating tone that belongs to the lexical root. The TV is underlyingly toneless (Girma 2015: 102). The inventory of verbal tonal melodies is based on the second person singular imperative form of a verb, because it is the simplest of all inflected verb forms. The following examples illustrate tonal contrast on nouns (1), adjectives (2) and verbs (3). Note that all the contrasting words have the same syllable structure:

(1) Nouns:
a. CVCV H.H bólí 'pumpkin'
H.L pát'ì 'thigh'
L.H pàlí 'girl'
b. $\quad C_{C} C_{1} V$
L.L tàmì 'fire'
H.H kízzí
H.L t'úbbì 'calf of leg'
L.H gìzzí 'money'
L.L Tàs's'ì 'tooth'
c. $\quad \mathrm{CVC}_{1} \mathrm{C}_{2} \mathrm{~V}$ H.H Rémsí 'moon'
H.L húldì 'donkey'
L.H Tànsí 'gold'

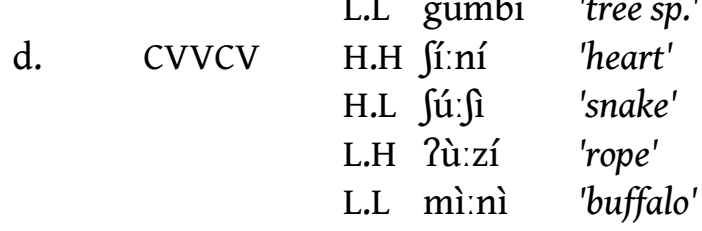
e. $\quad \mathrm{CVVC}_{1} \mathrm{C}_{2} \mathrm{~V}$ H.H bó:nzí 'leg'
H.L Jí:nt'ì 'nose'
L.H mè:ns'í 'glass ring'
L.L gò:yk'ì 'skin'
f. $\quad \operatorname{CCVVC}_{1} \mathrm{C}_{2} \mathrm{~V}$ H.H t'wé:nt'í 'worm'
H.L sjá:ns'ì 'bed'
L.H tjà:ndí 'heel'
L.L sjà:nsì 'fire place' 
(2) Adjectivs:
a.
CVCV
H.H Jílí 'close, near'
H.L kálì 'warm'
L.H Ràzí 'slim'
b. $\quad \mathrm{CVC}_{1} \mathrm{C}_{1} \mathrm{~V}$
L.L gìmì 'dirty'
H.H Jáppí 'bitter'
H.L kámmè 'straight, excellent'
L.H gàttí 'big, great'
L.L pàzzì 'sharp (of tip)'
c. $\quad \mathrm{CVC}_{1} \mathrm{C}_{2} \mathrm{~V}$ H.H húlt'í 'rotten'
H.L k'ántì 'jealous'
d. $\quad \operatorname{CVVC}_{1} \mathrm{C}_{2} \mathrm{~V}$ H.H já:nt'í 'soft'
H.L Rá:mp'ì 'fool'
L.H tà:ntí 'red, chocolate'
e. CCVVCV H.L kjá:mì 'dry'
f. $\quad \operatorname{CCVC}_{1} \mathrm{C}_{1} \mathrm{~V}$ H.L k'wéffi 'happy'
g. $\quad \operatorname{CCVVC}_{1} \mathrm{C}_{2} \mathrm{~V}$ L.H kwèmbí 'old'

(3) Verbs:
a. CVCV H.H Sómé 'Disappear!'
L.H k'às'é 'Do!'
b. $\quad \mathrm{CVC}_{1} \mathrm{C}_{1} \mathrm{~V}$ H.H húzzé 'Farm!'
$\begin{array}{lll} & \text { H.L hèzzé 'Hit!' } \\ \text { c. } \quad \mathrm{CVC}_{1} \mathrm{C}_{2} \mathrm{~V} & \text { H.H Púns'é 'Stand!' }\end{array}$
d. CVVCV H.H kó:lé 'Throw!'
L.H dò:k'é 'Stand!'
d. $\quad \mathrm{CVVC}_{1} \mathrm{C}_{2} \mathrm{~V}$ H.H hú:mp'é 'Steal!'
$\begin{array}{ll} & \text { L.H pà:nsé 'Jump!' } \\ \text { e. CCVCV } & \text { H.H tjámé 'Count' }\end{array}$
L.H k'jànsé 'Pass by, Step over!'

As can be observed, all of the possible combinations of the two tones, i.e. H.H, H.L, L.H and L.L melodies, have been attested on disyllabic nouns and adjectives. Disyllabic verbs show only H.H and L.H melodies. This is because the tone associated with the final syllable of the verbs underlyingly belongs to the second person imperative mood marker -é. On the basis of the facts, the surface tonal melody of disyllabic major word classes of Sezo can be summarized as follows: 


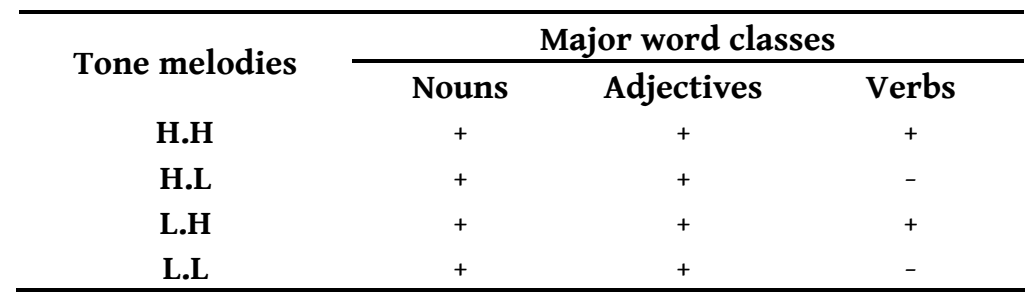

TABLE 1: Melody inventory of disyllabic major word classes.

In addition to the level tones, Sezo shows rising LH and falling HL contour tones on some nouns, adjectives and verbs. But these are attested only on bimoraic syllables-syllables consisting of long vowels. On some bimoraic syllables, the LH contour tone contrasts with the two level tones. The following are examples of words that show the rising LH contour tone:

(4) Nouns:

$$
\begin{gathered}
\text { LH.L fĩ:mì 'scorpion' } \\
\text { ใ̌̃:fi 'name }
\end{gathered}
$$

(5) Adjectives:

$$
\begin{aligned}
& \text { LH.L fã:mì 'tall, long' } \\
& \text { p̌i:wì 'bad' }
\end{aligned}
$$

(6) Verbs:

$$
\begin{aligned}
& \text { LH.H wě:nk'é 'Open!' } \\
& \text { pǎ:yé 'Swim!' }
\end{aligned}
$$

The falling HL contour tone has not been attested on isolated disyllabic and trisyllabic words. In citation form, only monosyllabic V-final nouns show the HL contour tone. Examples are given below:

(7) HL fî: 'excrement'

dî: 'father'

mî: 'grain'

In this study, contour tones are analyzed as fusions of the two level tones for various reasons. The first reason is related to their distribution. As mentioned earlier, contour tones are always realized on bimoraic syllables. Monomoraic syllables do not bear contour tones. Moreover, they are mostly found on V-final roots which are assumed to have lost their root consonants historically. For instance, the following V-final noun roots, which bear an LH contour tone on 
their root-internal long vowels, have C-final cognates in closely related languages such as Northern (Bambasi-Diddessa) Mao and Ganza. ${ }^{2}$

(8) Sezo

wă:-ì [wă:ji]

wě:-ì [wě:jì]
Bambasi-Diddessa Mao

walä

wakä
Ganza Gloss

wájà 'ear'

wàyà 'chicken'

This suggests that the $\mathrm{L}$ and the $\mathrm{H}$ tones, which synchronically form the $\mathrm{LH}$ contour tone on wě:- 'ear' and wă:- 'chicken', were historically distributed over two different syllables. They are squeezed together on one bimoraic syllable as a result of historical loss of consonant such as $/ \mathrm{l} /, \mathrm{k} /, \mathrm{j} / \mathrm{\text {and}} / \mathrm{y} /$. The same assumption also works for roots consisting of HL tone bearing syllables. The treatment of such contour tones as sequences of level tones is the usual analytical step (Yip 202:27).

The second evidence for the treatment of contour tones as composites of the two level tones comes from synchronic tonal processes that form the HL contour tone on bimoraic syllables. Synchronically, a HL contour tone can be formed by tonal processes, such as partial high-spreading and re-linking of a floating high tone to an adjacent non-floating low tone bearing bimoraic syllable (see § 6.3).

\section{[4] ACOUSTIC EVIDENCE FOR THE CONTRASTIVE TONES}

The following figures demonstrate the pitch tracks of contrastive tones attested on disyllabic nouns (Figures 1-5), adjectives (Figures 6-10) and verbs (Figures 11-13). All the words in the examples are as pronounced by the same male informant of about 27 years. According to the measurement, while the high tone produced by the informant is $\approx 52$ semitones, the low tone is $\approx 48$ semitones on average. But it should be noted that the pitches of the two tones may ascend above or descend below the average semitones based on the vocal range used by the informant at different recording times.

[2] The Bambasi-Diddessa Mao data are taken from Baye (2006) and Girma (2010). The Ganza data are from my own field note and Smolders (2015). 


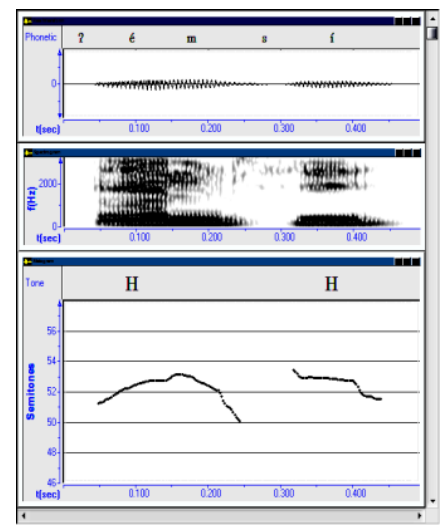

FIGURE 1: Rémsí (H.H) 'moon'

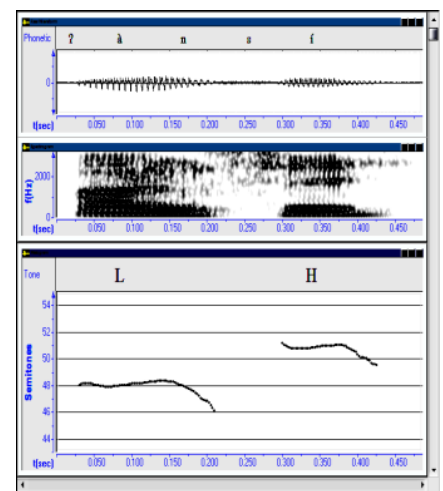

FIGURE 2: Tànsí (L.H) 'gold'

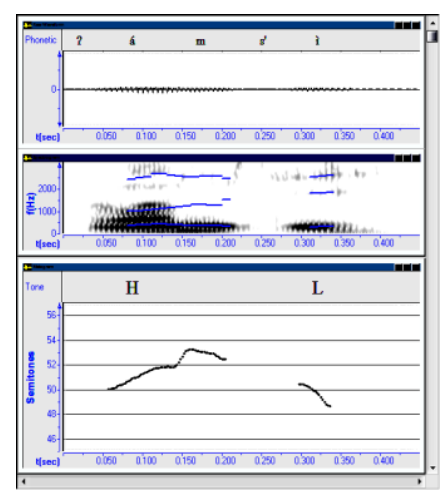

FIGURE 3: Ráms'ì (H.L) 'tears' 


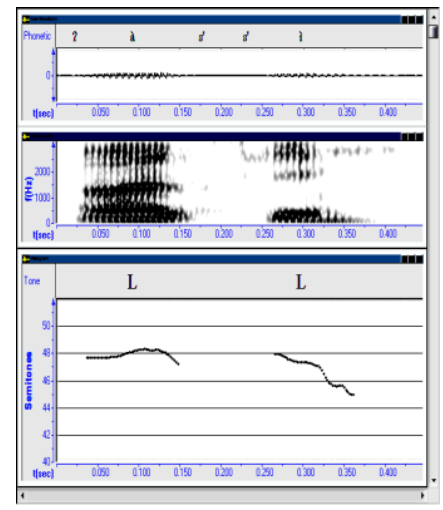

FIGURE 4: ?às's'ì (L.L) 'tooth'

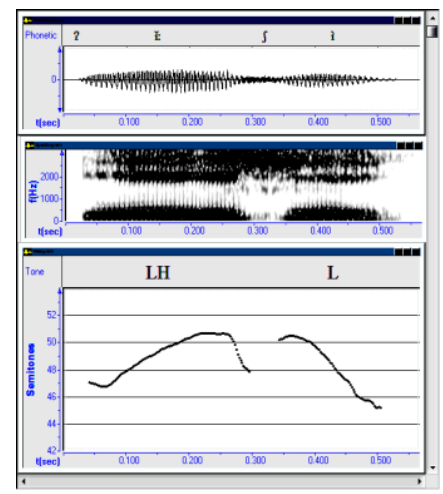

FIGURE 5: 21̌:jî (LH.L) 'name'

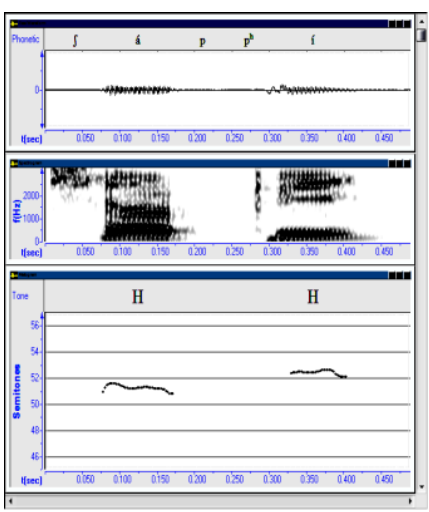

FIGURE 6: Jáppí (H.H) 'sour' 


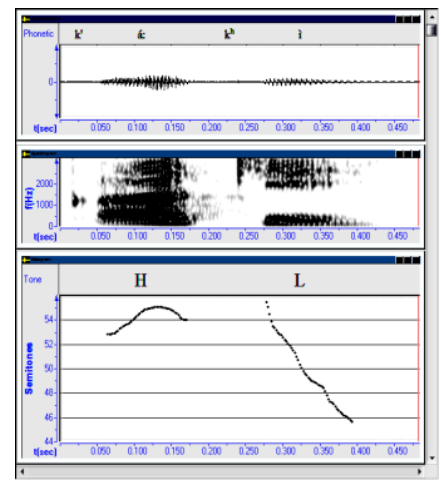

FIGURE 8: k'ákì (H.L) 'cold'

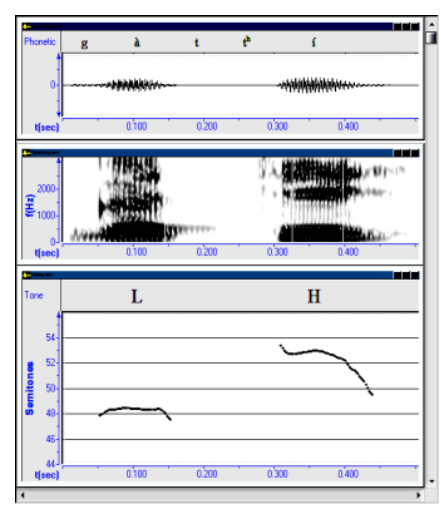

FIGURE 9: gàttí (L.H) 'big'

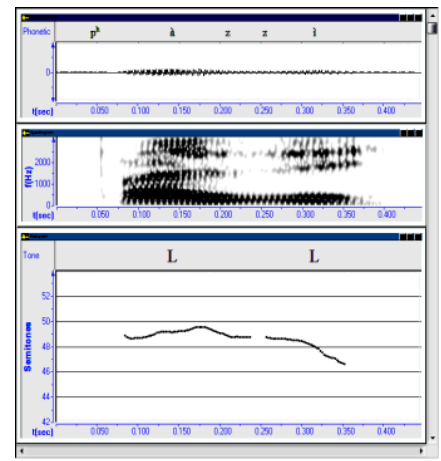

FIGURE 10: pàzzì (L.L) 'sharp (of tip)' 


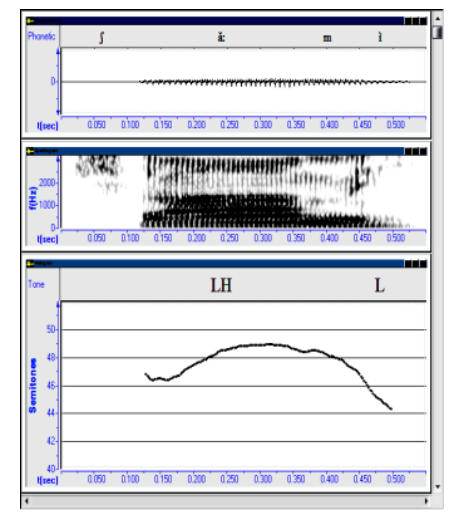

FIGURE 11: Jă:mì (LH.L) 'tall, long'

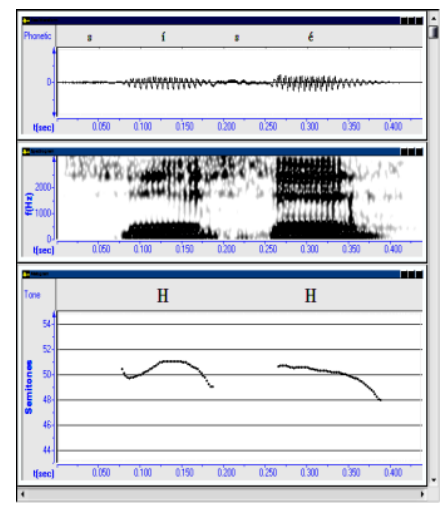

FIGURE 12: sísé (H.H) 'Shave! (2SG) '

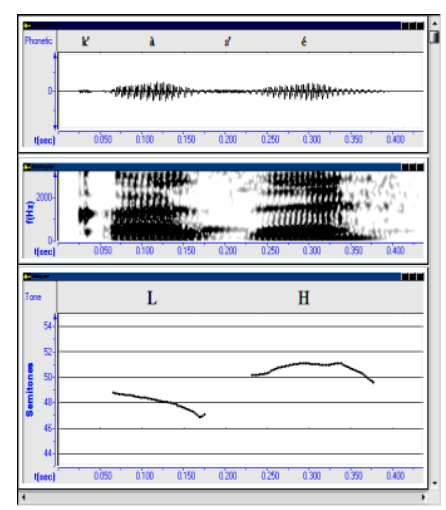

FIGURE 13: kàs'é (L.H) 'Work, do! (2SG) ' 


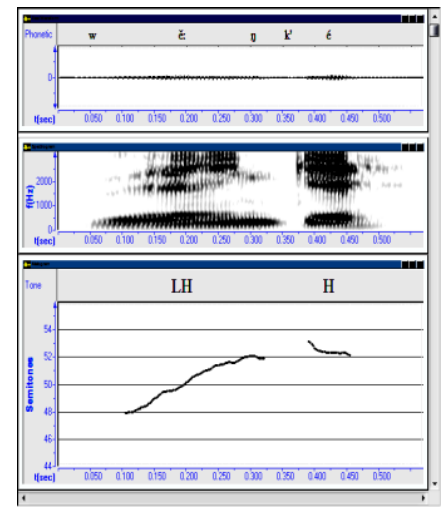

FIGURE 14: wě:yk'é (LH.H 'Open! (2SG)'

The pitch tracks in the above figures substantiate the different tonal melodies attested on disyllabic nouns, adjectives and verbs. While the tonal melodies attested on disyllabic nouns and adjectives are H.H, H.L, L.H, L.L and LH.L, those found on verbs of the same syllable structure are H.H, L.H and LH.H.

[5] THE FUNCTIONS OF TONE

\section{[5.1] Lexical function}

Changing lexical meaning

In Sezo, tone distinguishes the meaning of words. Tonal minimal pairs and triplets are very frequent in the language. The following tonal minimal pairs and triplets have been identified from a stock about 700 words: Tonal minimal pairs
a. H.L Tí:j
'honey'
LH.L IỸ:j
'name'
b. H.L kjá:jì
'egg'
L.L kjà:jì
'house'
c. HL Jî:
'excrement'
L $\quad$ il:
'forest'
d. H.L má:jì
'food'
LH.L mă:jì
'person'
e. H.L Tú:jì
'millstone'
LH.L Tǔ:jì
'hole in the ground'
f. H.L Já:yì
'outside, light (n)'
LH.L Jă:yì
'fly (n)' 


\begin{tabular}{|c|c|c|c|}
\hline \multirow[t]{2}{*}{ g. } & H.L & wíns'ì & 'tree sp.' \\
\hline & L.L & wìns'ì & 'paternal aunt' \\
\hline \multirow[t]{2}{*}{ h. } & H.L & mánì & 'right (n) \\
\hline & L.L & mànì & 'outside, a field in front of a house \\
\hline \multirow[t]{2}{*}{ i. } & Н.H & túgí & 'leg, foot' \\
\hline & H.L & túgì & 'pillar' \\
\hline \multirow[t]{2}{*}{ j. } & H.H & Pú:zí & 'hill' \\
\hline & L.H & Pù:zí & 'rope used to climb a tree' \\
\hline \multirow[t]{2}{*}{ k. } & L.H & tùlí & 'pushing' \\
\hline & H.L & túlì & 'returning' \\
\hline \multirow[t]{2}{*}{1.} & H.L & fáwì & 'stone' \\
\hline & Н.H & Jáwí & 'sharp (of edge), young, hero' \\
\hline \multirow[t]{2}{*}{ m. } & H.H & ká:ndí & 'warthog' \\
\hline & L.H & kà:ndí & 'groaning' \\
\hline \multirow[t]{2}{*}{ n. } & L.H & kè:sí & 'grain sp. (Eragrostis Abyissinica)' \\
\hline & H.L & ké:sì & 'finding' \\
\hline \multirow[t]{2}{*}{ o. } & H.L & kwé:jì & 'cooking' \\
\hline & L.L & kwè:jì & 'road, path' \\
\hline \multirow[t]{2}{*}{ p. } & H.L & Tí:nsì & 'tree' \\
\hline & L.H & Pì:nsí & 'be afraid of' \\
\hline \multirow[t]{2}{*}{ q } & H.L & wé:jì & 'shepherd, to look after animals' \\
\hline & LH.L & wě:jì & 'ear' \\
\hline \multirow[t]{2}{*}{ r. } & H.L & Rénì & 'tolerant' \\
\hline & L.H & Tèní & 'hunting' \\
\hline \multirow[t]{2}{*}{ s. } & H.L & Púlì & 'mounting, climbing' \\
\hline & L.H & Pùlí & 'garbage' \\
\hline \multirow[t]{2}{*}{ t. } & L.H & pè:k'í & 'heavy' \\
\hline & L.L & pè:k'ì & 'toad' \\
\hline \multirow[t]{2}{*}{ u. } & H.L & pát'ì & 'thigh' \\
\hline & L.H & pàt'í & 'antelope' \\
\hline \multirow[t]{2}{*}{ v. } & H.H & tá:yí & 'grain sp.' \\
\hline & LH.L & tă:yì & 'hit repeatedly' \\
\hline \multirow[t]{2}{*}{ w. } & L.L & wè:yk'ì & 'cardamom' \\
\hline & LH.L & wě:yk'ì & 'opening' \\
\hline \multirow[t]{2}{*}{$\mathrm{x}$. } & H.H & Támí & 'breast' \\
\hline & H.L & Pámì & 'gleaning' \\
\hline \multirow[t]{2}{*}{ y. } & H.H & Pé:wí & 'thing' \\
\hline & H.L & Té:wì & 'ripen' \\
\hline
\end{tabular}




$\begin{array}{llll}\text { z. } & \text { H.L } & \text { sá:sì } & \text { 'in old times' } \\ & \text { L.H } & \text { sà:sí } & \text { 'biting' } \\ & & \text { Tonal minimal triplets } & \\ \text { a. } & \text { H.L } & \text { dú:lì } & \text { 'era' } \\ & \text { L.H } & \text { dù:lí } & \text { 'hyena' } \\ & \text { LH.L dǔ:lì } & \text { 'family, relative, clan' } \\ \text { b. } & \text { H.L } & \text { á:mì } & \text { 'blind' } \\ & \text { L.L } & \text { fà:mì } & \text { 'cabbage' } \\ & \text { LH.L fã:mì } & \text { 'tall' } \\ \text { c. } & \text { H.L páfí } & \text { 'moral' } \\ & \text { H.L pàfì } & \text { 'porcupine's thorny hair' } \\ & \text { L.H } & \text { pàfí } & \text { 'planting' }\end{array}$

Noun derivation

In Sezo, verbal nouns and result nominals are derived from verbs by insertion of polar (opposite) tones in the root-final position of the verb roots. ${ }^{3}$ If the base verb carries an $\mathrm{H}$ tone on its root-internal first mora (counting from right to left), an $\mathrm{L}$ tone is inserted in the root-final position of the verb root to derive the nominal counterpart of the verb. If the base verb carries an L tone on its root-internal first mora (counting from right to left), an $\mathrm{H}$ tone is inserted in the root-final position of the verb root for the same purpose. At the surface level, the derivational polar tone is realized on the TV of the derived noun when the noun is cited in isolation. In Sezo, the function of a TV is to support the root-final floating tones of isolated nominals, that is to say, nouns and adjectives. The following tables illustrate the derivation of verbal nouns and result nominals.

[3] One might query whether the direction of the derivation is the other way around. In this study, I consider verbs as bases and their nominal counterparts as derivatives of the verbs, because it is possible to add grammatical morphmes to verb roots without adding any tonal element. But it is impossible to add nominal grammatical morphemes to the roots unless we add the root final derivational tones. In other words, before they take nominal grammatical morphemes, they have to be changed to nouns through insertion of a polar tone. 


\begin{tabular}{|c|c|c|c|c|c|c|}
\hline Verb root & Gloss & RIT & TDM & VN (UF) & VN (CF) & Gloss \\
\hline sís- & 'shave' & $\mathrm{H}$ & $\mathrm{L}$ & /sís `-/ & [sísì] & 'shaving' \\
\hline k'íw- & 'listen' & $\mathrm{H}$ & $\mathrm{L}$ & /kíw `-/ & [k'íwì] & 'listening' \\
\hline tjámm- & 'count' & $\mathrm{H}$ & $\mathrm{L}$ & /tjámm -/ & [tjámmì] & 'counting' \\
\hline t'á:y- & 'kick' & $\mathrm{H}$ & $\mathrm{L}$ & / t'á:y - & [t'á:yì] & 'kicking' \\
\hline Jí:f- & 'urinate' & $\mathrm{H}$ & $\mathrm{L}$ & / $1 \dot{1}: \int-/$ & 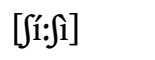 & 'passing urine' \\
\hline wě:nk'- & 'open' & $\mathrm{LH}$ & $\mathrm{L}$ & /wě:yk' -/ & [wě:yk'ì] & 'opening' \\
\hline kǒ:- & 'sit' & $\mathrm{LH}$ & $\mathrm{L}$ & / kǒ: '-/ & [kǒ:jì] & 'sitting' \\
\hline Sõ:- & 'walk & LH & $\mathrm{L}$ & / Sǒ: '-/ & [ ǒ:jì] & 'walking' \\
\hline k'às'- & 'work' & $\mathrm{L}$ & $\mathrm{H}$ & /k'às' '-/ & [k'às'í] & 'working' \\
\hline k'ìm- & 'talk' & $\mathrm{L}$ & $\mathrm{H}$ & / k'ìm '-/ & [k'ìmí] & 'talking' \\
\hline hèzz- & 'hit' & $\mathrm{L}$ & $\mathrm{H}$ & /hèzz'-/ & [hèzzí] & 'hitting' \\
\hline dò:k'- & 'stand' & $\mathrm{L}$ & $\mathrm{H}$ & /dò:k' -/ & [dò:k'í] & 'standing' \\
\hline pà:ns- & 'jump & $\mathrm{L}$ & $\mathrm{H}$ & /pà:ns'-/ & [pà:nsí] & 'jumping' \\
\hline
\end{tabular}

TABLE 2: Derivation of verbal nouns.

\begin{tabular}{|c|c|c|c|c|c|c|}
\hline Verb root & Gloss & RIT & TDM & RN (UF) & RN (CF) & Gloss \\
\hline Sí:- & 'urinate' & $\mathrm{H}$ & $\mathrm{L}$ & $/ \iint^{\prime}: \int-/$ & [fí:ji] & 'urine' \\
\hline hámbíl- & 'bleed' & $\mathrm{H}$ & $\mathrm{L}$ & /hámbíl `-/ & [hámbílì] & 'blood' \\
\hline k'éss- & 'perspire' & $\mathrm{H}$ & $\mathrm{L}$ & /k'éss `-/ & [k'éssì] & 'sweat' \\
\hline s'úl- & 'spit' & $\mathrm{H}$ & $\mathrm{L}$ & /s'úl '-/ & [s'úlì] & 'sputum' \\
\hline mál- & 'give birth' & $\mathrm{H}$ & $\mathrm{L}$ & /mál `-/ & [málì] & 'child' \\
\hline hù:ns'- & 'laugh' & $\mathrm{L}$ & $\mathrm{H}$ & /hù:ns'-/ & [hù:ns'í] & 'laughter' \\
\hline hùzz- & 'farm $(v)^{\prime}$ & $\mathrm{L}$ & $\mathrm{H}$ & /hùzz-/ & [hùzzí] & 'farm (n)' \\
\hline k'ìm- & 'talk' & $\mathrm{L}$ & $\mathrm{H}$ & /k'ìm-/ & [k'ìmí] & 'speech' \\
\hline
\end{tabular}

TABLE 3: Derivation of result nominal.

The following three pairs of graphs substantiate the claim that polar tones are derivational morphemes. They demonstrate the pitch tracks of verbs: sís-é 'Shave(2SG)', k'às'-é 'Work, do (2SG)' and dò:k'-é 'Stand (2SG)', which respectively show $\mathrm{H}, \mathrm{L}$ and $\mathrm{L}$ tones on their root-internal moras and that of the nominal counterparts of the verbs-[sísì] 'shaving', [kàsí] 'working' and [dò:k'í] 'standing', which respectively display the polar derivational tones $\mathrm{L}, \mathrm{H}$ and $\mathrm{H}$ on their TV. While the $\mathrm{H}$ tone associated with the second person singular imperative -é underlyingly belongs to the suffix, the polar derivational tones associated with TVs belong to the lexical roots. The TV is only a phonetic material inserted to host the root-final floating tones of isolated nominals. 


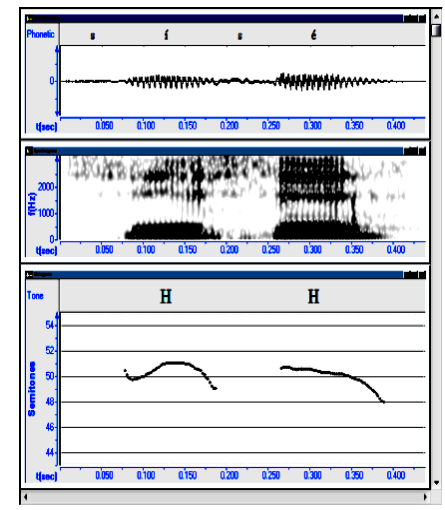

FIGURE 16.1: sísé (H.H) 'Shave ! (2SG)'

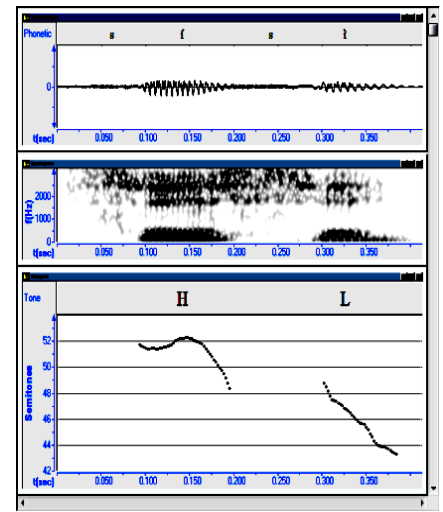

FIGURE 16.2: sísì (H.L) 'shaving'

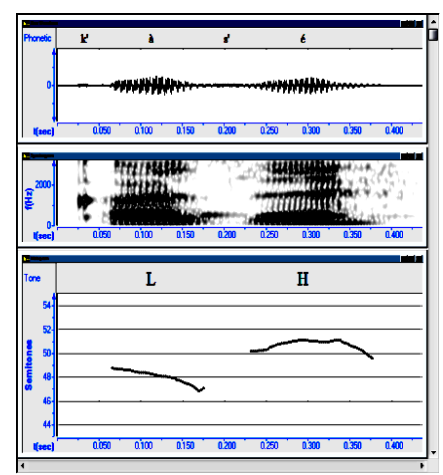

FIGURE 17.1: k'às'é (H.L) 'Work, do! (2SG)' 


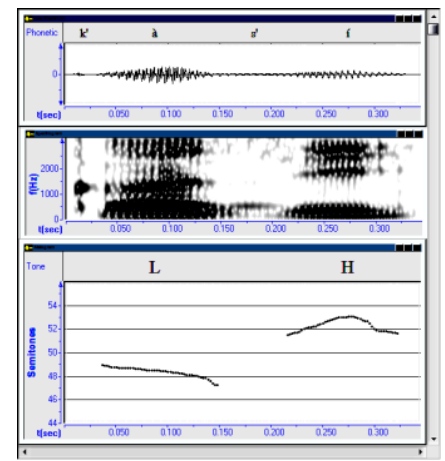

FIGURE 17.2: k'às'í (L.H) 'working, doing'

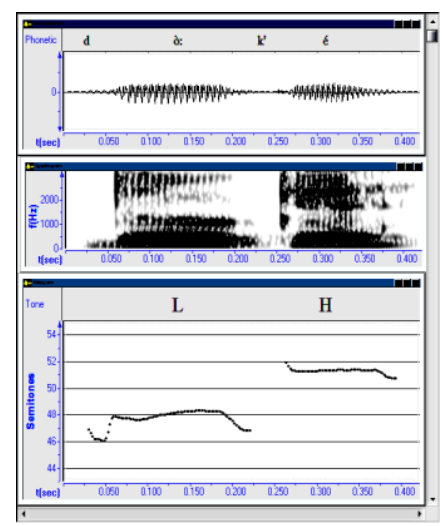

FIGURE 18.1: dò:k'é (L.H) 'Stand (up)! (2SG)'

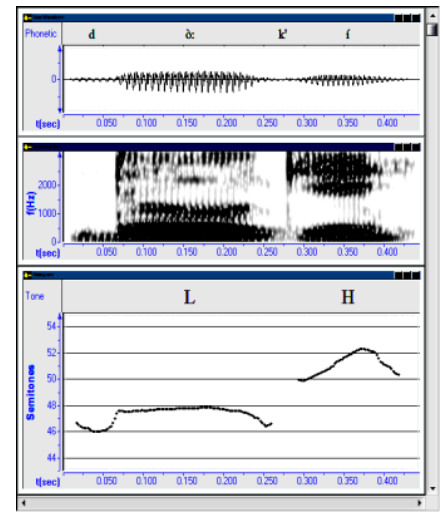

FIGURE 18.2: dò:k'í (L.H) 'standing (up)'

As can be observed from the pairs of figures, when the verb carries an $H$ tone on its root-internal TBU, its nominal counterpart bears an L tone on its TV. When the verb carries an L tone on its root-internal TBU, its nominal counterpart bears an $\mathrm{H}$ tone on its TV. As mentioned earlier, the tones borne by the TV 
are the polar derivational tones.

\section{[5.2] Grammatical function}

In Sezo the role of tone in the grammar is very limited. It distinguishes only between declarative and interrogative sentences. Whereas the declarative is marked by a high tone associated with the suffix -ár, its interrogative counterpart is indicated by a low tone associated with the same suffix. Consider the bold printed suffixes in the following examples.

(24) wànágì- $\int$ mà:máné kàrmá: bà:báb-té pì-n $\varnothing=\mathrm{kw}-a$ á: Wanagi-NOM Yesterday Karma Babane-DAT/LOC rise-CVB1 3SG.AGRS=Come-DCL 'Yesterday Wanagi came from Karma Babane.'

(25) wànágì- h hín-té pì-n kw-à:

Wanagi-NOM where-DAT/LOC rise-CVB1 come-DCL 'Where did Wanagi come from?'

\section{[6] TONAL PROCESSES}

In Sezo, a tone borne by one lexical or morphological element may affect a tone that belongs to a neighboring lexical or morphological element. It may trigger tonal processes such as downstep, downdrift, high-spreading, re-linking of a high tone, and delinking of a low tone. In the language, tonal processes may take place across morphemes and word boundaries. The following subsections describe tonal processes attested in the language.

\section{[6.1] Downstep}

Downstep is lowering of a high tone. It is triggered by a preceding floating or unassociated low tone (Yip 2002:148). In Sezo, a low tone that triggers a downstepping of an $\mathrm{H}$ tone may be stranded from its TBU in two ways - by deletion of a nominal TV or by total spreading of a high tone from the left.

In citation form, every nominal (noun and adjective) in Sezo consists of a root and a TV. As repeatedly mentioned, the function of a TV in Sezo is to host the root-final floating tone of isolated nominals. But when such nominals are followed by morphological or syntactic constituents, their TV gets deleted, leaving the tone it bears floating. In Sezo, a L tone delinked from its host TV triggers a following $\mathrm{H}$ tone to be downstepped. For instance, when an H.L tone bearing adjective like ká:wì 'black' is used to pre-modify an H.H tone bearing noun like bólí 'pumpkin', the adjective deletes its TV and occurs as ká:wø̀- 'black' to form a single utterance group together with the noun it modifies. Conse- 
quently, the $\mathrm{L}$ tone delinked from the deleted TV of the adjective remains behind by floating and triggers downstepping of the $\mathrm{H}$ tone hosted by the adjacent syllable of the modified noun. The process can be illustrated by the following autosegmental notations introduced by Goldsmith (1976). In autosegmental representation, elements in the tonal and segmental layers are linked to each other with 'association lines'. The disconnection of elements in the two layers is indicated by an equal sign (=) cutting across an association line. An encircled tone represents a floating tone.

(16) The adjectives and the nouns in citation form

a. ká:wì<smiles>C1=CCC1</smiles>

$\mathrm{H} \quad \mathrm{L}$

'white'

b. bólí<smiles>[CH]1CC1</smiles>

$\mathrm{H} \mathrm{L}$

'pumpkin'

(17)

The adjectives and the nouns in modifier-modified relation

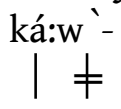

$\mathrm{H} \quad \mathrm{L}$

'white pumpkin' tbólí

${ }^{\llcorner} \mathrm{HH}$

The following figures depict the acoustic representation of the isolated nominals in (16) and the downstepping process demonstrated in (17).

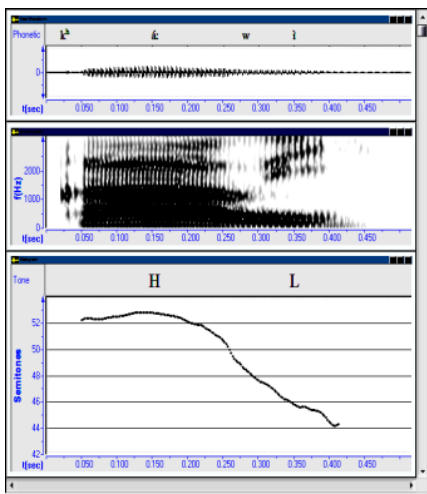

FIGURE 19: ká:wì (H.L) 'white'

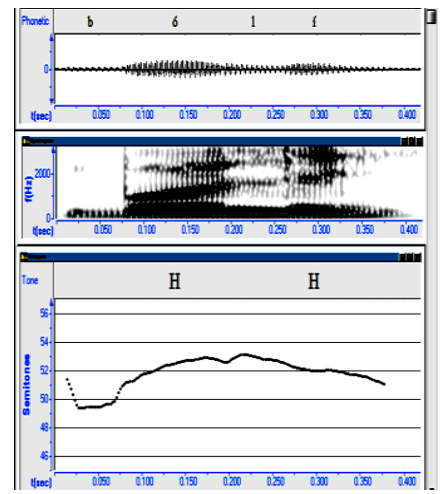

FIGURE 20: bólí (H.H) 'pumpkin' 


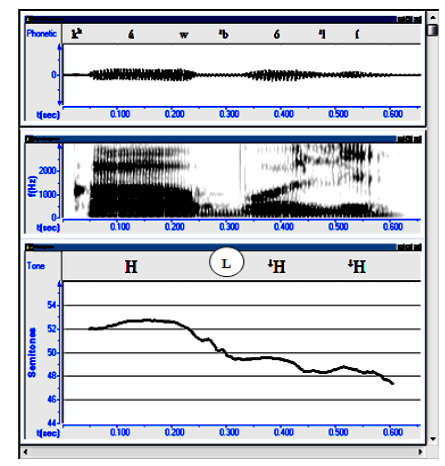

FIGURE 21: ká:w bólí (H.H) 'white pumpkin'

As can be observed, in citation form, the noun bólí 'pumpkin' bears a high tone ( $\approx 52$ semitones) on both its first and last syllables (cf. Figure 20 ). But this high tone is lowered to $\approx 49$ semitones when the noun is pre-modified by the adjective ká:wì 'black' (cf. Figure 21). What triggers the downstepping is the adjectival root-final floating tone that is delinked from its deleted host: viz. TV [i]. The lowering of the $\mathrm{H}$ tone borne by the ultimate syllable of the pre-modified noun bólí 'pumpkin' is a result of a pause feature (cf. Figure 21).

A floating $\mathrm{L}$ tone that triggers an $\mathrm{H}$ tone to be downstepped may also be stranded from its TBU as a result of $\mathrm{H}$ spreading from the left. Spreading is the association of the tone of one TBU to an adjacent TBU by feature discharging (Yip 2002). When an $\mathrm{H}$ tone associated with a TBU of a separate morpheme spreads to the right over a monomoraic $L$ tone bearing syllable of an adjacent morpheme (constituent), it delinks the L tone (since there is no enough space to accommodate the two tones) and associates itself with the TBU of the stranded $\mathrm{L}$ tone. As a result, the delinked $\mathrm{L}$ tone stays behind by floating and triggers the downstepping of an adjacent $\mathrm{H}$ tone. Compare the pitch tracks of the $\mathrm{H}$ tone associated with the ultimate syllables of the noun Jikkí ' $k n i f e$ ' in the following graphs: 


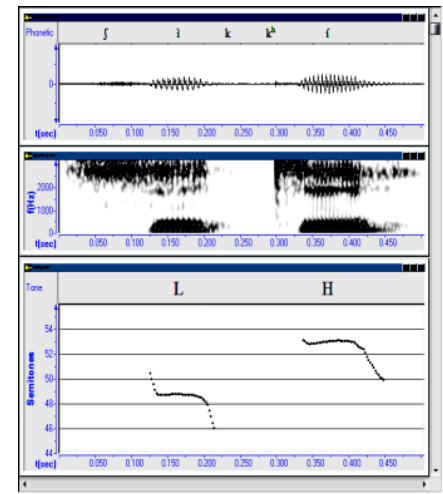

FIGURE 22: jikkí 'knife' (H.H)

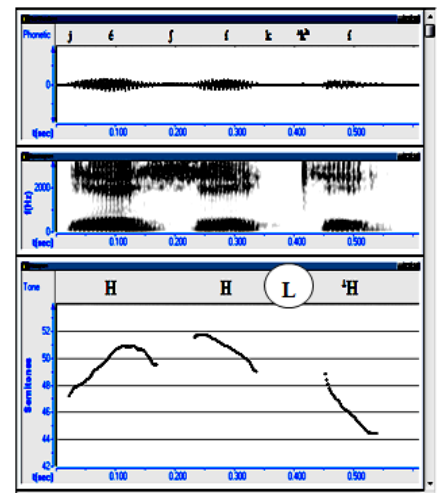

FIGURE 23: jé-fík kí (H.H. 'H) 'the knife'

In citation form, the noun fikkí ' knife' bears a L ( $\approx 49$ semitones) and a high ( $\approx 53$ semitones) tone respectively on its penultimate and ultimate syllables, as in Figure 22. But when it occurs with the definite marker jé-, the $\mathrm{L}$ tone associated with the first syllable of the noun is changed to an $\mathrm{H}$ tone ( $\approx 51$ semitones), as displayed in Figure 23. On the contrary, the $\mathrm{H}$ tone associated with the ultimate syllable of the definite noun is realized at a very low pitch ( $\approx 46$ semitones). The two changes are the results of different tonal processes. First, the $\mathrm{H}$ tone associated with the definite article jé- ( $\approx 51$ semitone) spreads over the first syllable of the noun Jikkí 'knife' delinks the L tone from its TBU and associates itself to the $\mathrm{L}$ tone bearing unit. The delinked tone remains by floating and then lowers the pitch of the $\mathrm{H}$ tone borne by the ultimate syllable of the definite noun. The processes can be illustrated as follows. A dotted association line indicates spreading of the tone feature.

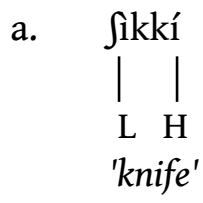

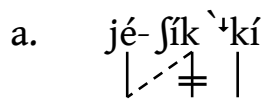

\section{$\mathrm{H} \quad \mathrm{L} \quad \mathrm{H}$ \\ 'The knife'}

This above autosegmental representation shows the $\mathrm{H}$ spreading to the right, the delinking of the $\mathrm{L}$ tone and the downstepping of the $\mathrm{H}$ tone of the ultimate syllable of the noun. 


\section{[6.2] Downdrift}

Downdrift is a tonal process whereby a $\mathrm{H}$ tone after an overt $\mathrm{L}$ tone is realized at a lower height of pitch, compared to a preceding $\mathrm{H}$ tone (Yip 2002:148). It is a gradual downward inclination of pitch from the beginning of utterance to the end (Fox 2000:189). In Sezo, it is a common tonal process observed in longer utterances such as phrases and sentences. Let us look at the high tone borne by the ultimate syllable of Jikkí ' $k n i f e$ ' in isolation and in a phrase. In this study, both downstep and downdrift are represented by a down arrow $\left(^{(}\right)$superscribed on the onset of a syllable.
a. má:nzì<smiles>CI</smiles> 'small'
b. Sikkí
$\mathrm{L} \quad \mathrm{H}$
'knife'
c. má:nzø̀ $\int \mathrm{ik} \mathrm{k}^{\mathfrak{k}}$
'small knife'

Note that the lowering of the pitch of the high tone on the final syllable of fikkí 'knife' in (19-a) is not a downstep because it is not triggered by a floating low tone. It is found after an overt low tone associated with the TBU of the first syllable of the noun. The following Figures respectively demonstrate the pitch tracks of the un-lowered (19-b) and the lowered (19-c) high tone of the noun fikkí 'knife' as pronounced by the native speaker mentioned earlier. 


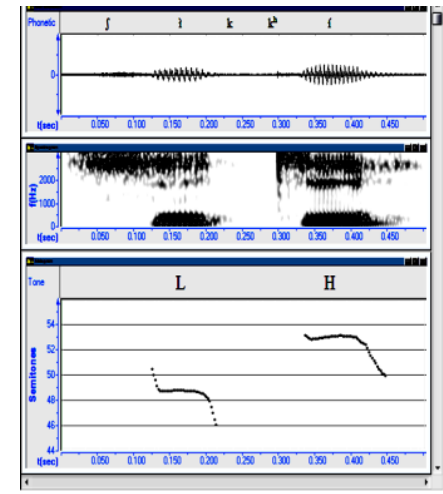

FIGURE 24: Jikkí (L.H) 'knife'

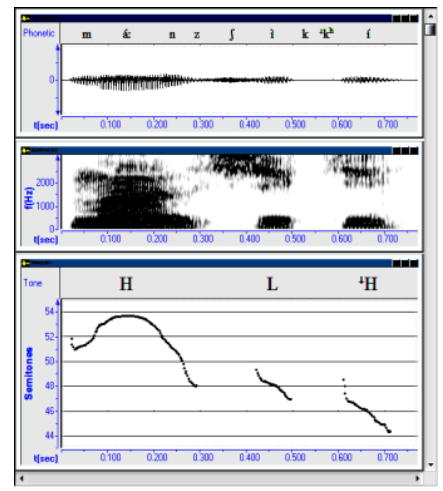

FIGURE 25: má:nz- fikkí

As can be observed, when the noun fikkí 'knife' is cited in isolation, the pitch of the high tone associated with the final syllable of the noun is $\approx 53$ semitones (cf. Figure 24). But when the noun is pre-modified by adjective má:nzì 'small' it drops down to $\approx 48$ semitones (cf. Figure 25 ). It is lower than the pitch of the preceding L tone.

\section{[6.3] Formation of a falling contour}

A falling HL contour tone can be formed through two synchronic tonal processes. These are partial high-spreading and re-association of a floating $\mathrm{H}$ tone to a $\mathrm{L}$ tone bearing unit. In Sezo, an HL contour tone is formed only on bimoraic syllables, viz. syllables consisting of long vowels. The two processes are separately described below.

\section{Partial spreading of a high tone}

In Sezo, if an $\mathrm{H}$ tone belonging to one morpheme spreads rightwards over a bimoraic $\mathrm{L}$ tone bearing adjacent syllable, it always forms a HL contour because there is enough space to accommodate the two tones (because there are two morae/moras). This process is referred to as partial high-spreading, because it does not delink the L tone from its TBU. The HL contour tone borne by the penultimate syllable of the following definite noun (20-b) is formed by a feature discharged from the $\mathrm{H}$ tone associated with the definite prefix. That the $\mathrm{HL}$ contour tone is a result of partial high-spreading is clear from the indefinite counterpart of the noun which displays a basic L.H tonal melody (20-a).

(20) a. tà:lí

$\mathrm{L} \mathrm{H}$

'chief' 


\section{b. jé-tâ: ‘lí

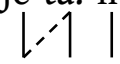 \\ $\mathrm{H} \quad \mathrm{L}^{\downarrow} \mathrm{H}$ \\ 'The chief'}

The following figures demonstrate the pitch tracks of the above indefinite and definite nouns:

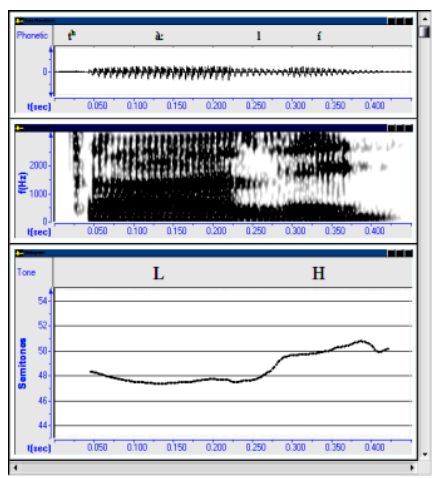

FIGURE 26: tà:lí 'chief' (L.H)

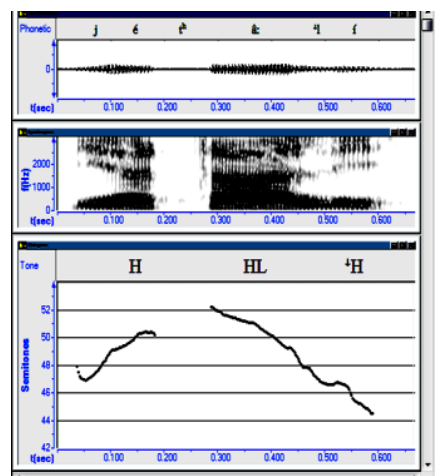

FIGURE 27: jé-tâ: Hí (H.HL. H) 'the chief'

As can be observed from Figure 26, while the tone borne by the first syllable of the indefinite noun tà:lí 'chief' is an L tone ( $\approx 48$ semitones), the tone hosted by the final syllable of the same noun is $\mathrm{H}(\approx 50$ semitones). But when the noun occurs with the definite marker jé-, the tone borne by the first syllable of the noun is changed to HL (the pitch starts at $\approx 51$ semitones and declines down to $\approx 48$ semitones (cf. Figure 27). The HL contour is a result of partial highspreading. Note that the lowering of the $\mathrm{H}$ tone associated with the final syllable of the definite noun is a result of downdrift as well as a pause feature.

De-linking and re-linking of a high tone

The other tonal process whereby a falling contour is formed, is the reassociation of a stranded $\mathrm{H}$ tone to an $\mathrm{L}$ tone bearing bimoraic syllable. This process usually takes place across word boundaries when a nominal category deletes its $\mathrm{H}$ tone bearing TV to form a single phonological unit with an adjacent syntactic or morphological element. For instance, when an L.H tone bearing disyllabic adjective like gàttí 'big' pre-modifies an L.H tone bearing disyllabic noun like twàzí 'hoe', the TV of the adjective gets deleted, leaving the root-final $\mathrm{H}$ tone behind. Following the deletion of the TV, the stranded $\mathrm{H}$ tone moves rightwards and re-associates itself with the first syllable of the modified noun. Eventually it forms a falling (HL) contour, together with the L tone originally borne by the first syllable of the noun. On bimoraic syllables, $\mathrm{H}$ tones do 
not displace $\mathrm{L}$ tones, because there is enough space to accommodate the two tones. In terms of autosegmental representation, the process can be illustrated as follows. Note that the down arrow in example (21-c) represents a downdrift and a pause feature.

(21)
a. gàttí
$\mathrm{L} \mathrm{H}$
'big'

b. twà:zí

$$
\begin{gathered}
\mathrm{L} \\
\text { 'hoe' }
\end{gathered}
$$

c. gàttø-twâ: ‘zí

$\begin{array}{llllll}\mathrm{L} & \mathrm{H} & \mathrm{L} & { }^{\perp} \mathrm{H}\end{array}$

'big hoe'

The following Figures display the actual acoustic representation of 21-a, 21-b and 21-c.

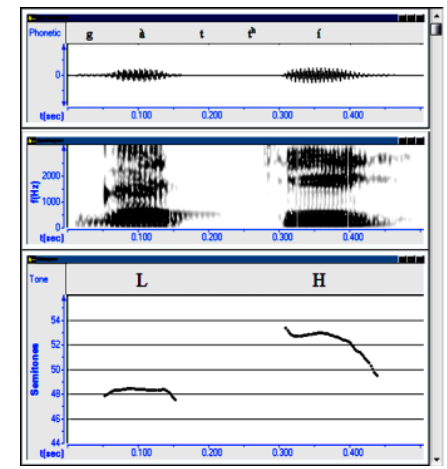

FIGURE 28: gàttí (L.H) 'big'

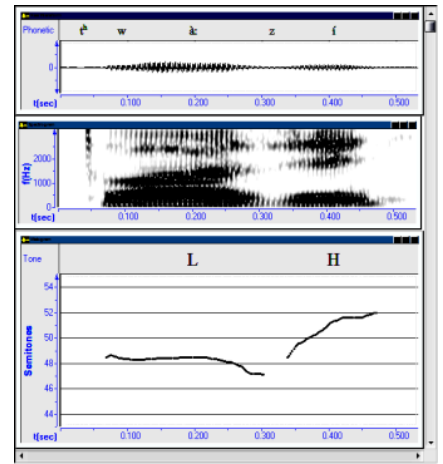

FIGURE 29: twà:zí (L.H) 'hoe' 


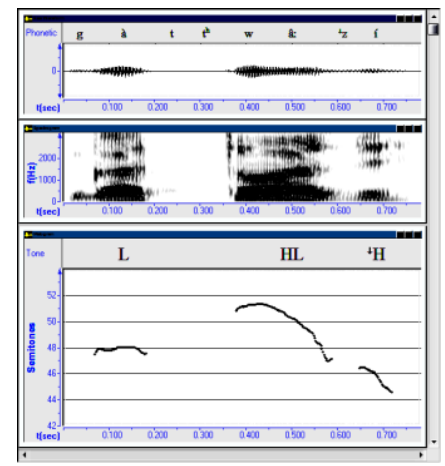

FIGURE 30: gàtt-twâ: 'zí (L.HL. 'H) 'big hoe'

As can be observed, in citation form, the noun twà:zí 'hoe' shows a low tone ( $\approx 48$ semitones) on its first syllable (cf. Figure 29). But when the noun is premodified by the adjective gàttí 'big', the tone on the same syllable starts at $\approx 51$ semitones and glides downwards to $\approx 48$ semitones (Figure 30 ). This is clearly a HL contour tone formed by the merger of an unassociated high tone from the left and an associated L tone borne by the first syllable of the modified noun. Note that the pitch of the high tone on the final syllable of the noun is very low, i.e. $\approx 46$ semitones (Figure 30 ). This is a result of the downdrift and pause feature.

\section{[6.4] Total spreading of high tone}

In Sezo, a high tone of a separate morpheme may spread over a neighboring low tone bearing monomoraic syllable across the morpheme boundary. When a high tone spreads over a monomoraic syllable, it does not form a HL contour, because the syllable does not have enough space to accommodate the two tones. It delinks the low tone from its TBU and totally replaces it. The following is a typical example of a total spreading of high tone. Note that the indefinite noun gìzzí 'money' has a low tone on its first syllable when it is cited in isolation.

(22)

a. gìzzí

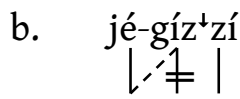

$\mathrm{H} \quad \mathrm{L}^{\perp} \mathrm{H}$

'The money' 
The following are respectively graphic representations of examples (22a) and (22b):

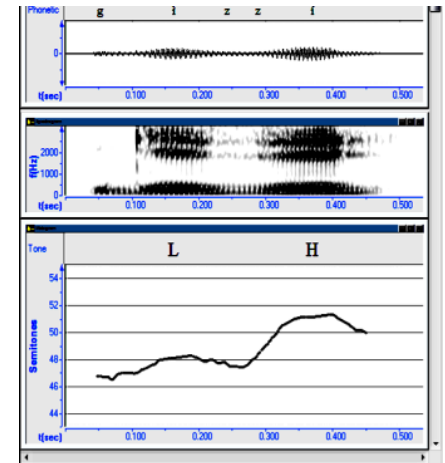

FIGURE 31: gìzzí (L.H) 'money'

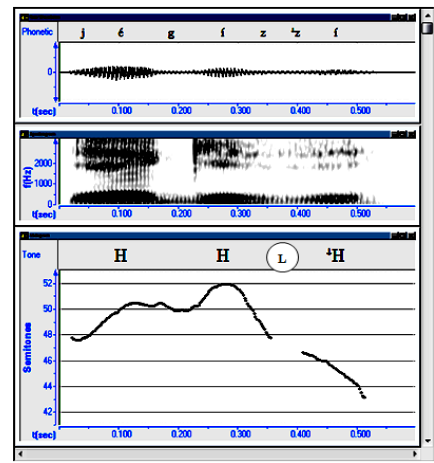

FIGURE 32: jé-gíz zí (H.H. H) 'the money'

As can be observed, the tone associated with the first syllable of the indefinite noun gìzzí 'money' is $\approx 48$ semitones (Graph 31 ). But this is changed to $\approx 52$ semitones when the noun occurs with the definite marker (Graph 32). This suggests the displacement of the low tone from its original TBU by a total spreading of a high tone from the left, i.e. from the definite article. The displacement of the low tone is clear from the downstepping phenomenon observed on the final syllable of the noun.

\section{[7] CONCLUSION}

This paper has shown that Sezo has two levels of tone - high and low. It has demonstrated that the two tones occur on monomoraic and bimoraic syllables (i.e. on short and long vowels). Rising (LH) and falling (HL) contour tones have been recorded occurring only on bimoraic syllables. These are analyzed as composites of the high and low tones squeezed together on one bimoraic syllable as a result of diachronic and synchronic processes. The study has shown that tone has a very significant role in the lexicon of the language. It is used to distinguish lexical items and derive nominal stems from verbal roots. The only function of tone in the grammar of the language is to make distinction between declarative and interrogative sentences. The basic tonal processes attested in the language are downdrift, downstep, contour formation through partial spreading of a high tone over a low tone bearing unit, contour formation through re-linking of a floating high tone to an adjacent low tone bearing unit and total spreading of a high tone. 
ABBREVIATIONS AND SYMBOLS

$\begin{array}{llll}\text { ACC } & \text { accusative } & \text { RN } & \begin{array}{l}\text { result nominal } \\ \text { AGRS }\end{array} \\ \text { subject agreement } & \text { TDM } & \begin{array}{l}\text { tonal derivational morpheme } \\ \text { underlying form }\end{array} \\ \text { C } & \text { consonant } & \text { UF } & \text { vowel } \\ \text { CF } & \text { citation form } & \text { V } & \text { verbal noun } \\ \text { CVB } & \text { converb } & \text { VN } & \text { verb root } \\ \text { DAT/LOC } & \text { dative/locative } & \text { VR } & \text { first person } \\ \text { DCL } & \text { declarative } & 1 & \text { second person } \\ \text { H } & \text { high } & 2 & \text { third person } \\ \text { L } & \text { low } & 3 & \text { high tone } \\ \text { NOM } & \text { nominative } & \checkmark & \text { low tone } \\ \text { IMP } & \text { imperative } & \checkmark & \text { rising (LH) contour tone } \\ \text { INTER } & \text { interrogative } & \checkmark & \text { falling (HL) contour tone } \\ \text { RIT } & \text { root-internal tone } & \wedge & \text { downstep, downdrift } \\ \text { SG } & \text { singular } & \downarrow & \text { delinked tone } \\ \text { TV } & \text { terminal vowel } & \neq & \end{array}$

\section{REFERENCES}

Baye Yimam. 2006. A General Description of Mao. In ELRC Working Papers. Addis Ababa University: AAU Printing Press. vol.2, no.2, 166-255

Fleming, Harold C. 1984. Mao's Ancestor. Consonant Phonemes of Proto-Mao: Stage One. In A. Garmoyoko (ed.). Proceedings of the Ninth International Conference of Ethiopian Studies. Moscow: Nauka. 35-44.

Fox, Anthony. 2000. Prosodic Features and Prosodic Structure: The Phonology of Suprasegmentals. Oxford: oxford University Press.

Girma Mengistu Desta. 2010. The Morphosyntax of Verbal Functional Categories of Diddessa Mao. VDM Verlag Dr Müler Aktiengeselleschaft and Co. KG: Dudweiler Landstr. (Originally an MA thesis submitted to Addis Ababa University, 2007).

Girma Mengistu Desta. 2015. A Grammar of Sezo. Addis Ababa: Addis Ababa University (unpublished Ph.D. dissertation).

Goldsmith, John A. 1976. Autosegmental Phonology. PhD dissertation, MIT.

Smolders, Joshua. 2015. A wordlist of Ganza. Addis Ababa: SIL Ethiopia.

Yip, Moira 2002. Tone. Cambridge: Cambridge University Press. 
CONTACT

Girma Mengistu Desta

Addis Ababa University

girmeng.desta@gmail.com 